\title{
Jane Austen's Views on Marriage in Pride and Prejudice
}

\author{
Feifei Pei, Changle Fu, Xiaolin Huang \\ Air Force Logistics College, Xuzhou, China \\ Email: sisi612@163.com
}

Received 30 July 2014; revised 28 August 2014; accepted 28 October 2014

Copyright (C) 2014 by authors and Scientific Research Publishing Inc.

This work is licensed under the Creative Commons Attribution International License (CC BY). http://creativecommons.org/licenses/by/4.0/

(c) (i) Open Access

\begin{abstract}
Jane Austen, one of women writers, was famous for her realistic writing style. Among her works, Pride and Prejudice is a world-famous masterpiece, in which she created four different marriages, and showed us her views on marriage. The views have some guiding significance to our modern women even now.
\end{abstract}

\section{Keywords}

Jane Austen, Views on Marriage, Elizabeth, Guiding Significance

\section{Introduction}

Jane Austen was a famous realistic woman writer of late $18^{\text {th }}$ century and early $19^{\text {th }}$ century. Born in a clerical family and educated strictly, Jane Austen created six novels and three unfinished stories, during just 42 peaceful years, and was considered to be a prolific writer.

Among the works, Pride and Prejudice is the most successful and impressive masterpiece. The famous novel was written in 1813, and was very popular all the time and had been read widely. It showed the daily lives and values of the Middle-Class Englishmen of that time, which was Male-Centered. Many people simply regard Pride and Prejudice as a love story, but in my opinion, this book is an illustration of the society at that time. Jane Austen perfectly reflected the relation between money and marriage at her time and gave the people in her works vivid character.

The characters have their own personalities. Mr. Bennet is an old-style gentleman. Mrs. Bennet is a woman who makes great efforts to marry off her daughters. Mr. Bingley is a friendly young man, but his friend, Mr. Darcy is very proud. Mr. Darcy seems to always feel superior. Even the five daughters in Bennet family are very different. Jane is simple, innocent and never speaks evil of others. Elizabeth is a clever girl who always has her own opinion. Mary likes reading classic books who actually is a pedant. Kitty doesn't have her own opinion but 
likes to follow her sister, Lydia. Lydia is a girl who follows exotic things, handsome man, and is somehow a little profligate. The parents, the daughters, and even the young men are all representative personages of different groups. That's why when we read the book, we can easily find the same personalities in the modern society now. Indeed, the book is the representative of the society in Britain in the late $18^{\text {th }}$ century and the early $19^{\text {th }}$ century.

The family of gentlemen in the countryside is Jane Austen's favorite topic, because this little topic can reflect big problems. It concludes the stratum situation and economic relationships in Britain in her era. People always think that Austen was an expert at telling love stories. In fact, the marriage in her book is not the result of love, but the result of economic needs. After reading this book, everyone will go to think deeply about what love is and what marriage is.

In this essay, we will talk about the four marriages in this novel, Jane Austen's marriage values, and its practical significance to modern people.

\section{Four Marriages in Pride and Prejudice}

Jane Austen weaved four marriages in Pride and Prejudice. The four marriages are all different from each other. Through these different marriages, Jane Austen showed us the true social problems and characteristics of that time, and implied her own values of marriage.

\subsection{Collins and Charlotte}

In the novel, when the homely and plain Charlotte decided to marry Collins, she was only satisfied, without thinking highly either of men or of matrimony, marriage had always been her object, and we can see it was the only honorable provision for well-educated young women of small fortune.

In fact what Charlotte asks is only a comfortable shatter, a higher social position and a better wealth. She once explained to Elizabeth, "I am not romantic, you know. I never was. I ask only a comfortable home; and considering Mr. Collins character, connections, and situation in life, I am convinced that my chance of happiness with him is as fair, as most people state" (Austen, 1970).

For Collins, he is a man who does not know what love is at all. When Mr. Collins first proposed to Elizabeth, much to her mother's displeasure and her father's joy, she firmly and promptly rejected him. He almost immediately transferred his affections to Elizabeth's best friend, Charlotte Lucas, who, 27 and somewhat homely, accepted at once his offer of marriage. Collin's decision to marry Charlotte is only because of Elizabeth's refusal to him. What he needs is just a wife who helps him not to be a single man any longer.

\subsection{Lydia and Wickham}

We know that, in the novel, Lydia, as Mr. Bennet's third daughter, was spoilt by her mother, so she was very conceited and arrogant, and behave frivolously. Wickham, he has no other advantage except for his attractive physical appearance. In his opinion, love is just recreation. Due to he was trouble with a large debt, he entices Lydia and gets her love easily. When their love does not get the permission from the parents, they elope. When Elizabeth hears the news, she believes that their love does not have a happy ending. Indeed, Wickham would not marry Lydia, because she was no charming and has nothing to attract him. He does not love her but the wealth of her family.

\subsection{Jane and Bingley}

Jane was the oldest of Mr. Bennet daughter, a pretty girl of sweet and gentle disposition. Bingley was an immediate success in local society. At the first ball, Jane has a good impression of Bingley, and it is the same to Bingley. They were attracted to each other at once. After the ball, "When Jane and Elizabeth were alone, the former, who had been cautious in her praise of Mr. Bingley before, expressed to her sister how very much she admired him” (Austen, 1970).

For Bingley, he had a good temper. He was so modest and had no opinion about his own marriage. No matter how obvious his attachment to Jane was, he believed Darcy's representation of Jane's indifference was true. Because Mr. Bingley's two sisters didn’t like Jane, they thought Mr. Bingley should choose Darcy's sister as his wife, who was of cause "superior" to Jane. Under the influences of his sisters and Mr. Darcy, Bingley began to doubt Jane's affection to him. Finally, he thought Jane didn’t love him, so he left her without saying goodbye. 
Later, when all the misunderstanding clarified, he came back to Jane at Darcy's assistance. Bingley's indecisive character determines his happiness and results that this life was controlled by others. Later on a visit to Bingley's, Jane's love affair with Bingley is advanced. Even Bingley is apparently on the point of proposing to Jane. Actually Bingley is attracted by Jane's tenderness and beautiful appearance, while Jane is attracted by his gentle manner. They love each other.

\subsection{Darcy and Elizabeth}

As the heroine of this novel, Elizabeth's love is very important. At the beginning, Elizabeth refused to accept Darcy's pursue. Because in Elizabeth's mind, Darcy is very cold and extremely proud, he is rich and has high social status, and he look down upon the middle-class girls. In particular, he insulted Elizabeth Bennet, a girl of spirit and intelligence and his father's favorite. But as time goes by, Darcy began to admire Elizabeth in spite of himself.

For Elizabeth, love is the most important element of marriage. She does not accept a marriage which is not based on love. She does not love Collins, so she refused the future heir to the manor and the wealth. And at first she thought Darcy was too arrogant, so she also refused the wealthy gentleman. We can see a rational and intelligent girl in the novel, who is just Elizabeth. As they knowing each other further and further, Elizabeth cleared the misunderstanding between them, and Mr. Darcy see the disadvantages in himself, they fell in love with each other on the basis of love. This is the best ending for them.

\section{The Writing Background of Pride and Prejudice}

As a most well-known female writer in the history of English literature, was born in Steventon on December 16, 1775. And she lived peacefully in a small social circle all her life. She was the youngest of seven children in her family. She received most of her education at home. Her family are all fond of reading books, which influenced her very much. Her reading extended little beyond the literature of the $18^{\text {th }}$ century, and within that period she admired Dr. Johnson particularly. Later she was delighted with both the poetry and prose of Scott, she died on July $18^{\text {th }} 1817$ and she never married. Austen was buried in the cathedral in Winchester (Kaplan, 1994).

In all her novels, the love affairs and marriages of young people, though serious and sympathetic, is subdued by humor to the ordinary way of narration, in which most of us live. She was the founder of the novel which deals with unimportant middleclass people and of which there are many fine examples in latter English fictions. Her style is easy and effortless. In these novels, the life of the gentry, landowners, and clergy of the late $18^{\text {th }}$ century and the early $19^{\text {th }}$ century is shown in detail.

Jane Austen's father was a country vicar, so Jane took for granted that a person should be sincere, unselfish, disinterested and unworldly, and that virtue should be judged by good sense and good taste. These beliefs are fundamental to her work. Throughout her life Jane Austen had been guided by Christian principles, and she accepted the Church's teaching without question. Her faith is implicit in all her writing: the virtues of a disciplined life, a caring relationship between husband and loving upbringing, are both reflected in her novels.

\section{Jane Austen's Views on Marriage in Pride and Prejudice and Its Guiding Significant to Modern People}

Jane Austen once wrote in her book, "It is a truth universally acknowledged that a single man in possession of a good fortune must be in want of a wife" (Gillie, 2005). Readers of Jane Austen can easily find out what marriage means and how important social status is to women of Austen's time.

In Jane Austen's mind, mutual attraction is the most important thing of a marriage. One who betrays his or her heart will never own true love. True love is much more cherishing than money and social position. This is what Austen puts a great deal of emphasis on. The heroine in the fiction, Elizabeth, is a loyal follower of her own affection. She encourages Jane to pursue true love with Bingley, and has disagreement of Caroline's overflowing flattery of Darcy for the purpose of only marring a gentleman whose fortune and position are a great appeal to herself, regardless of the affection. In face of Mr. Collins's proposal, Elizabeth refuses him without hesitation, since she knows that, the gentleman does not love her, but thinks that she is fit to be his wife, considering her character, her appearance and her family background. Actually, Elizabeth is on behalf of Jane Austen. She expresses everything that Austen wants to express. They both believe that a happy marriage is grounded upon mu- 
tual attraction. The marriage between Elizabeth and Darcy typically shows that we should not simply judge a person from the first sight of appearance and impression. It takes time to understand each other completely, and to get a pure appeal to each other.

However, when Elizabeth pursues the true love in the marriage, she does not avoid money problem. She admits that true love is the basis of a happy marriage, but money or wealth actually, should be the guarantee. Because a marriage will be unstable without the guarantee of money, and no matter how true their love is. When they cannot afford an easy life, their marriage is also going to fall apart.

People of $21^{\text {st }}$ century are equal with one another, and women can totally control their own future. They do not need to depend on a wealthy and powerful man, and they do not lower themselves to please men. Women in modern time have much more choices and get enough respect. But when thinking about marriage, Jane Austen's views still have some guiding significance. We should remember what Jane Austen and Elizabeth told us in the novel, that never marry a man, whom you don't love, and then imagine the condition of material life after your honeymoon.

\section{References}

Austen, J. (1970). Pride and Prejudice. Oxford: Oxford University Press.

Gillie, C. (2005). The Preface to Austen. Peking: Peking University Press.

Kaplan, D. (1994). Jane Austen among Women. Baltimore: Johns Hopkins University Press. 
Scientific Research Publishing (SCIRP) is one of the largest Open Access journal publishers. It is currently publishing more than 200 open access, online, peer-reviewed journals covering a wide range of academic disciplines. SCIRP serves the worldwide academic communities and contributes to the progress and application of science with its publication.

Other selected journals from SCIRP are listed as below. Submit your manuscript to us via either submit@scirp.org or Online Submission Portal.
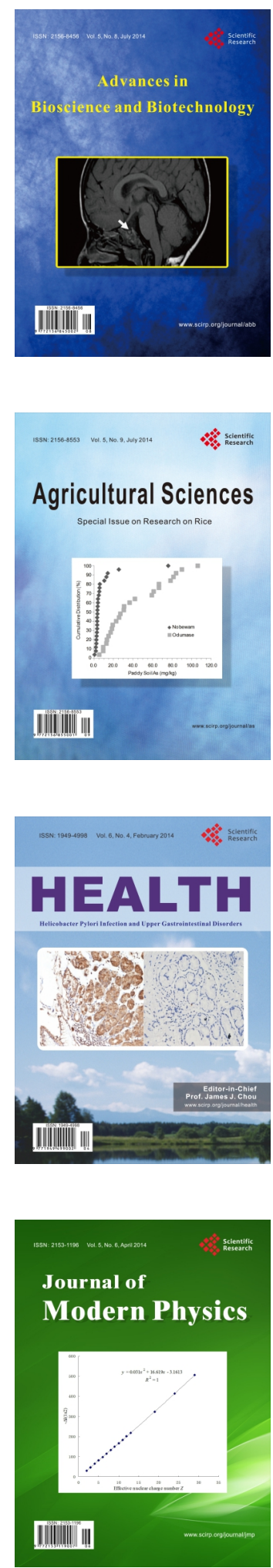
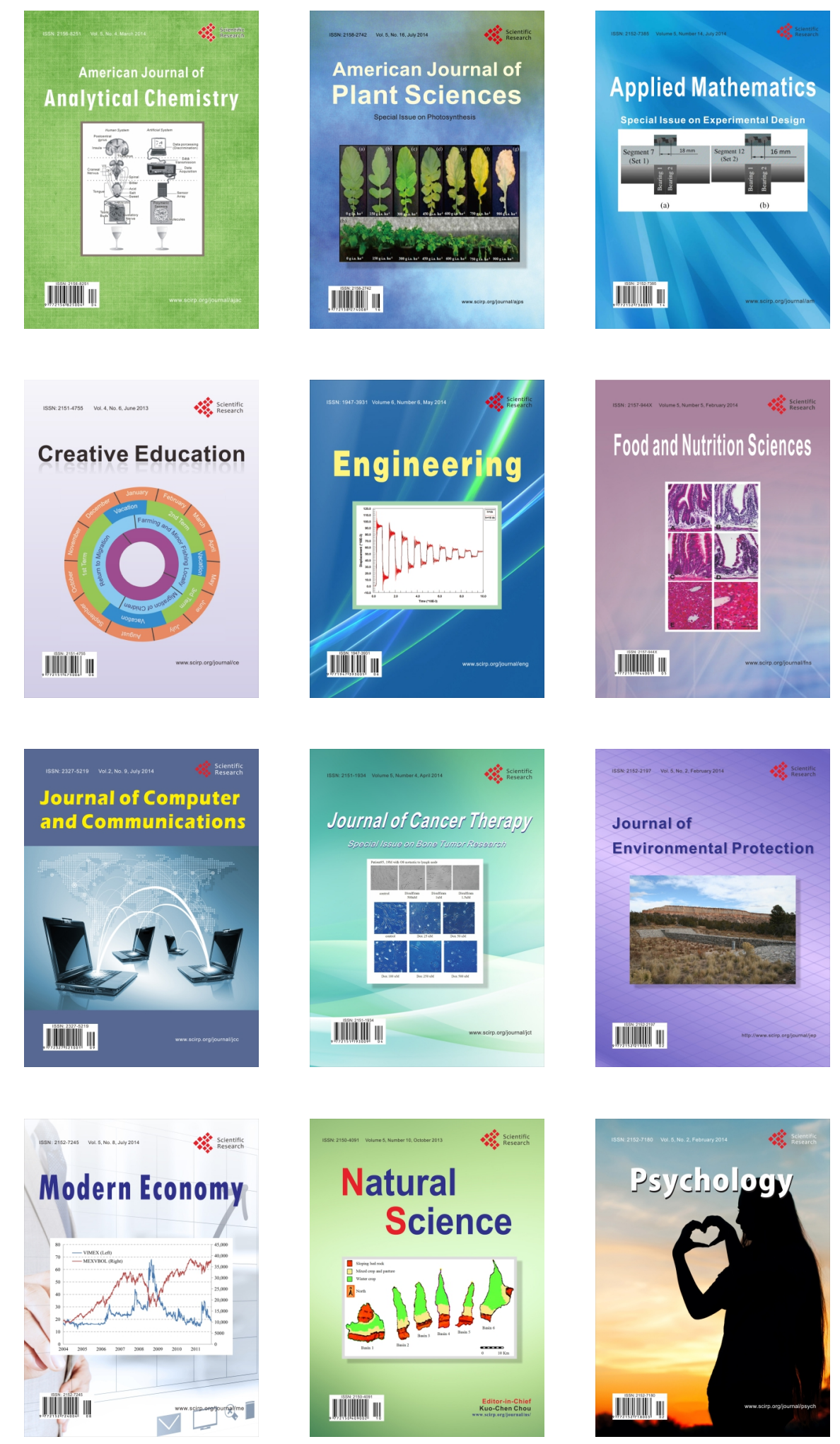